\title{
Impact of the domestic labor market on sustainability of agriculture in Oman
}

\author{
${ }^{\text {"}}$ Hemesiri Kotagama and ${ }^{1}$ Hanam Al Farsi
}

$$
\text { تأثير سوق العمل الحلي على استدامة الزراعة في عمان }
$$

$$
\text { حيميسيري كوتاجاما"1 وحنان الفرسي1 }
$$

ABSTRACT. In 2013, only 16\% of households in Oman have reported agriculture as the main occupation and 53\% have reported non-agricultural government employment as the main occupation, whilst the balance is employed in the private and non-formal sectors. This situation is hypothesized to be related to the labor market; where government legislated higher remuneration in the non-agricultural government sector vis-a-vis agricultural sector, influences Omani farmers to move to non-agricultural employment, causing reduced cultivated area and farm production. The study uses operations research methods to quantify the impact of labor market policies on agricultural employment, farm gross income and land use intensity. In an national average farm of 0.9 ha with 1.33 persons of family labor available, only $75 \%$ land use intensity is achieved, with a gross income of $1061 \mathrm{OMR} /$ Year/Household, which is below legislated minimum income for low skilled employment in the non-agricultural government sector (4632 OMR/Year/Household). The household gross income would increase to 5304 OMR/Year/Household with non-agricultural employment of 1 person and 0.33 persons in agricultural employment, which explains low employment of Omani's in agriculture. Farms of 2.1 ha (5 Feddans), with availability of 1.33 family labor earns a gross return of $2502 \mathrm{OMR} /$ Year/Household, which is again less than the salary in the non-agricultural government sector. However, with the current government policy of allowing to hire 1 expatriate laborer per 2.1 ha with 1 Omani person in non-agricultural employment and 0.33 family labor in agricultural employment, gross income increases to 6414 OMR/Year/Household and further if temporary labor hiring is allowed at peak farm labor requirements, gross income could be increased to $6632 \mathrm{OMR} /$ Year/Household. The current policy on hiring 1 expatriate labor per 2.1 ha along with non-agricultural employment of Omani labor is in the short-run optimal.

KEYwORDS: Labor market; Agriculture; Oman; Government policies

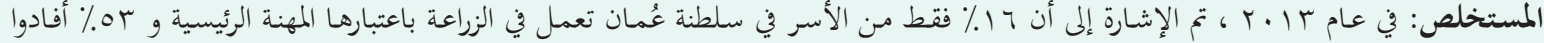

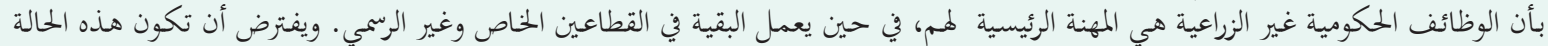

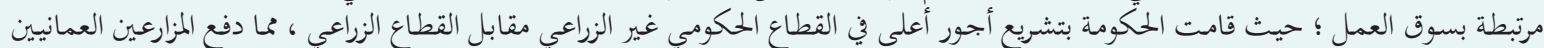

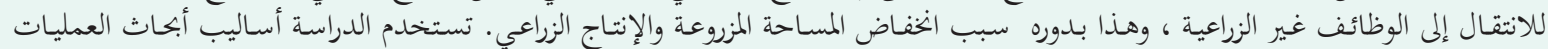

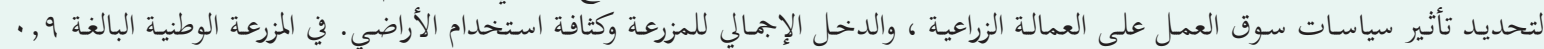

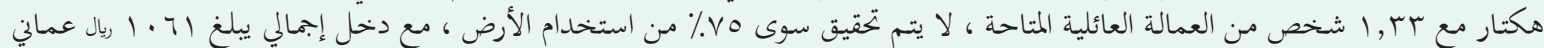

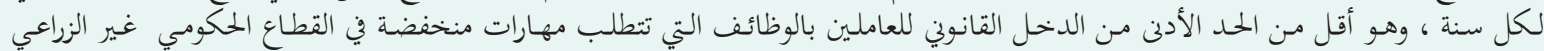

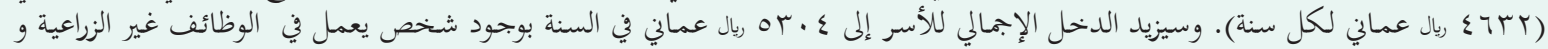

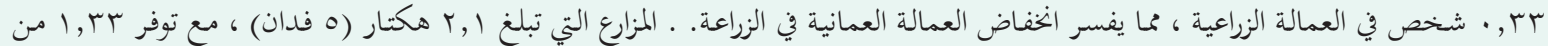

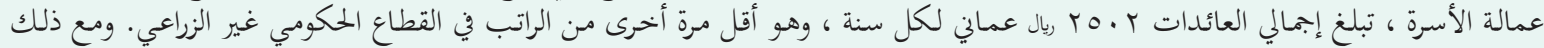

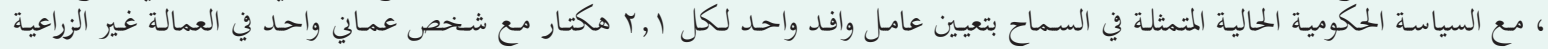

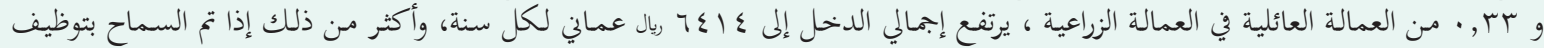

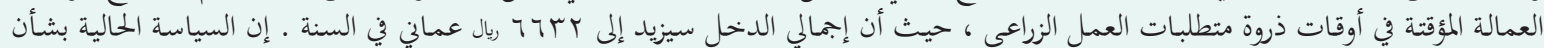

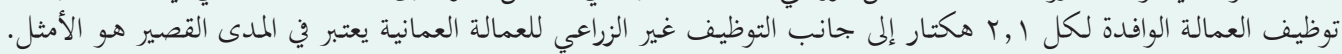

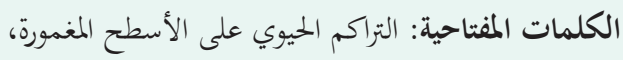

\section{Introduction}

$\mathrm{O}$ man being highly dependent on oil revenue since the 1970's, has recently adopted a policy of revenue diversification, in which the agricultural sector is expected to contribute prominently. However, the substantial exodus of Omani labor from

"Hemesiri Kotagama $(\gtrsim)$ Assistant Professor and Student, respectively at the Department of Natural Resource Economics, College of Agricultural and Marine Sciences, Sultan Qaboos University, Sultanate of Oman. Corresponding author: hemkot@squ.edu.om. agriculture to non-agricultural employment poses a challenge to sustainable improvement of agriculture and national food security. According to Agricultural Census of Oman in 2013 only 16\% of households in the agricultural sector have reported farming as the main occupation and $53 \%$ have reported government employment as the main occupation, whilst the balance is employed in the private and non- formal sectors (MAF 2013). This may be due to the distorted labor market; where government legislated, higher remuneration in the non-agricultural sector vis-a-vis agricultural sector, influences 
farmers to move labor to non-agricultural employment. Theoretically, undistorted factor markets are a prerequisite for efficient allocation of resources and a growth in production. This study with the use of operations research methodology quantifies the impact of distorted labor markets on farm revenue, farm land use intensity (proxy of production) to examine the role of labor markets in sustaining domestic agricultural production and national food security in the Sultanate of Oman.

\section{Literature Review}

Apergis et al. (2014) based on a study conducted on Middle East and North African countries, for the period of 1970 to 2011 concluded that the boom in the oil sector have had an adverse effect on the agricultural sector. This effect has been attributed to the well-known "Dutch disease" phenomenon, where in particular, the economic boom in the oil sector would increase real wages in the oil related non-agricultural sector, siphoning labor out of the relatively low waged agricultural sector (Reed 2012). The labor allocation between agricultural (on-farm) and non-agricultural (off-farm) sectors has been widely examined and reviewed (Donnellan and Hennessy 2012) and most empirical studies have examined and established the factors causing households to allocate labor from agricultural to non-agricultural employment. These factors include endogenous factors such as intra-household joint decision making between spouses, family size, educational status of individuals, farm income risk, the type of farming system in terms of size and enterprises, and exogenous factors such as labor market considerations, transaction cost of transfer from agricultural to non-agricultural employment, rates of urbanization, government subsidies to different sectors, government payments to non-agricultural labor (Donnellan and Hennessy 2012). Most of the studies are based on the seminal theoretical model proposed by Becker (1965) on household labor allocation and have used econometric methods to establish causative reasons on the shift of agricultural to non-agricultural employment. In contrast, studies examining the effect of non-agricultural employment on agricultural production and productivity are few (Nasir and Hundie 2014). Non-agricultural employment may have both positive impacts on farm productivity through supply of finance (Mathenge and Tschirley 2007) and/or negative impacts of moving labor out of agriculture and constraining its availability to agricultural production (Nasir and Hundie 2014). The studies suggest that the net impacts of labor shift from agriculture to non-agricultural employment may impinge adversely on local food production and food security.

In Oman, as table 1 indicates, in 2012 the main employment (by income) of Omani "farmers" has been mostly in the non-agricultural government sector (52.9\%), whereas agricultural employment has been only
Table 1. Farmer's main employment

\begin{tabular}{lll} 
Main Employment & Farmers & \% of total \\
\hline Agricultural & 9595 & 15.9 \\
Government sector & 31821 & 52.9 \\
Non-agricultural private sector & 7387 & 12.3 \\
Other & 1360 & 2.3 \\
Unknown & 10005 & 16.6 \\
Total & 60168 & 100.0 \\
Source: $M A F(2013)$ & &
\end{tabular}

15.9\% (MAF 2013). Thus the indications are that Omani farmers are leaving agriculture and opting for non-agricultural employment and expatriate labor is substituting Omani agricultural labor. The causes and implications of this phenomenon on farm production have not been empirically examined to date and are undertaken by this study.

\section{Methodology}

The hypothesis of this study is that the shift of agricultural to non-agricultural employment of Omani labor is caused by labor market conditions of relative remunerations of agricultural and non-agricultural sectors, which households consider in labor allocation decision making. Becker (1965) proposed that households maximize utility, which is a function of consumption of commodities and time allocated between work and leisure. Becker's proposition could be used to model farm household decision making where the household is considered to maximize utility, over consumption (with income as a proxy) generated through agricultural production and its sales and allocation of labor between agricultural, non-agricultural labor and leisure (Singh, Squire and Strauss 1986; Huffman and Lange 1989; Gould and Saupe 1989; and Weersink, Nicholson and Weerahewa 1998).

A farmer is considered to maximize utility $(U)$ which is function of consumption $(C)$ and leisure time $(L)$, as expressed by equation (1) subject to constraints of time (T) and household budget. $T$ is finite and is allocated between leisure $(L)$, off-farm (nonagricultural) labor $(O)$ and on-farm (agricultural) labor $(F)$ as expressed by equation (2). Consumption of commodities $(C)$ is dependent on returns to labor and commodities purchased at price $P_{c^{*}} C$ is constrained by the budget (equation 3 ) where $C$ at its extreme is considered to be equal to income and income is dependent on agricultural labor $(O)$ and its wage $(w)$, and the agricultural profit. The agricultural profit is the product of price of farm products $\left(P_{\mathrm{f}}\right)$ and volume of production $\left(Y_{\mathrm{f}}\right)$ less the cost of production, which is the product of cost of farm inputs $\left(I_{\mathrm{f}}\right)$ including labor that could be hired and volume of inputs $\left(X_{\mathrm{f}}\right)$. The non-agricultural wage $(w)$ depends on labor market conditions. The farmer in maximizing utility 
(equation 1) would allocate time between agricultural labor, non-agricultural labor and leisure, constrained to available labor $(\mathrm{T})$ and consumption possibilities that are dependent on income derived of agricultural production and non-agricultural income. The farmer in the constrained maximization of utility, at optimum would equate the marginal utilities of time allocated of labor between agricultural, non-agricultural and leisure.

$$
\begin{array}{ll}
\text { Maximize: } U=f(C, L) & \text { Eq. }(1) \\
\text { Subject to constraints of: } & \\
T=L+O+F & \text { Eq. }(2) \\
\text { C.P } P_{\mathrm{c}}=w \cdot O+\left(P_{\mathrm{f}} \cdot Y_{\mathrm{f}}-I_{\mathrm{f} \cdot} X_{\mathrm{f}}\right) & \text { Eq. }(3)
\end{array}
$$

The theoretical model elicited above on household labor allocation, is applied in this study, with simplified assumptions of considering a single household decision maker, maximizing utility on monetary gain, and ignoring many other complexities and realities (as reviewed in section 2). The structure of the theoretical model is applied to a farm context using linear equations and solved using a linear programming algorithm. The proxy for utility is considered income derived from agricultural production and non-agricultural income, which is maximized constrained to agricultural production and labor availability (family and hired labor) and labor market conditions. Agricultural production of crop and livestock, is dependent on, resource availability and technology of production. The farm linear programming model is given below as equations (4) to (7). The model considers annual farm production, as non-agricultural employment is considered to be annually fixed. Two seasons of vegetable and forage crop cultivation is considered with annual crop extent that is fixed.

Maximize:

$\pi f\left(\Sigma P_{\mathrm{i}} \cdot Y_{\mathrm{i}}+\sum P_{\mathrm{a}} \cdot A_{\mathrm{a}}+w_{\mathrm{o}} \cdot O-w_{\mathrm{h}} \cdot H\right)$

Subject to constraints of:

$$
\begin{aligned}
& \sum C_{\mathrm{ij}} Y_{\mathrm{i}}+\Sigma C_{\mathrm{ij}} \cdot A_{\mathrm{i}} \leq X_{\mathrm{j}} \\
& \sum C_{\mathrm{il} l} \cdot Y_{\mathrm{i}}+\Sigma C_{\mathrm{il}} \cdot A_{\mathrm{i}}+1 O-1 H \leq X_{\mathrm{l}} \\
& Y \mathrm{i} \geq 0
\end{aligned}
$$

\section{Where:}

$\pi$ is gross margin (Omani Rials, OMR/Year),

$P_{\mathrm{i}}$ are gross margins $(\mathrm{OMR})$ per ha of land

of ith crop,

$Y_{\mathrm{i}}$ are ha of land of alternative i crops,

$P_{\mathrm{a}}$ is the price (OMR) of a farm animal a,

$A_{\mathrm{a}}$ is the number of farm animals sold per year of a;

$w_{\mathrm{O}}$ is the non-agricultural wage (OMR/Person/Year),

$O$ is persons of non-agricultural labor allocation

(Persons/Year),

$w_{\mathrm{h}}$ is wage of hired labor (OMR/Person/Year),

$H$ is persons of hired labor,

$C_{\mathrm{ij}}$ are input-output coefficients of land, water and labor on production of crops and animals, $X_{\mathrm{j}}$ are available input levels of land $(\mathrm{Ha})$, water (Cu.M./Year),

$X_{1}$ is available family labor (Persons/Year) and

hired labor is unlimited but at a cost of $w_{\mathrm{h}}$

(OMR/Person/Year).

The data were obtained from published sources, namely: The Agricultural Census of Oman (MAF 2013), Report on Cost of Crop and Livestock Production in Oman (MAF 2008), and a Study on Profitability Analysis of Selected Farms in the Batinah Region of Oman (Al Said et al. 2007). The sustainability of farming systems in Oman is analyzed by simulating the impact of labor allocation changes caused by non-agricultural labor wages on: household income (OMR/Year/Household) and land use intensity. The land use intensity is estimated as: (Land cultivated during Spring + summer/ Land Owned $\left.^{*} 2\right)^{*} 100$. Land use intensity is considered as a proxy of domestic food production which relates to food security. More than $70 \%$ of the farms in Oman are less than 0.42 ha ( 1 Feddan) and these farms account for only $7.0 \%$ of the total cultivated area. About $75 \%$ of the farms by area cultivated are larger than 2.1 ha (5 Feddans). Farm land ownership is such that 90\% farmers own 25\% land area vs $10 \%$ farmers own $75 \%$ of land. The national average farm size is of 0.9 ha. The government of Oman has stipulated a legal limit of hiring 1 expatriate laborer per 2.1 ha. Based on the nature of farm size and ownership and legal conditions of hiring expatriate labor, two scenarios are analyzed viz; small farms of 0.9 ha and large farms of 2.1 ha. The minimum wage of non-agricultural employment is considered as 386 OMR/Month as legislated by the government (Royal Decree 2013) on standardized grades and salaries schedule for Omani civil employees of the state. The wage of hired expatriate labor is considered as $60 \mathrm{OMR} /$ Month excluding provision of food, accommodation and other associated fixed cost of recruiting expatriate labor.

\section{Results and Conclusion}

The optimization results of a national average size 0.9 a farm (scenario 1), with different labor allocation possibilities, are given in table 2. In Oman a family is classified as poor if it spends more than $60 \%$ of the household expenditure on food (MNE, 2010). Accordingly the poverty line is approximately $300 \mathrm{OMR} /$ Month/Household for an average household size of 8.5 members (Mbaga and Kotagama 2010). It is observed in table 2 row (1) that the gross revenue from a 0.9 ha farm is 1061 OMR/ Year/Household which is far below the national poverty threshold defined above which is 3600 OMR/Year/ Household. As mentioned above $70 \%$ of the farms are less than .42 ha (1 Feddan). Further farm income which is only $88 \mathrm{OMR} /$ Month/Household is substantially lower than the minimum wage offered to unskilled labor by the non-agricultural government sector, which is 386 OMR/Month/Person. Thus, there is a compulsive incentive to move away from agricultural to non-agricultural 
Table 2. Farm optimization results for 0.9 ha farm (scenario 1 )

\begin{tabular}{|c|c|c|c|c|c|c|c|}
\hline \multirow[t]{3}{*}{ Labor Allocation } & \multirow[t]{3}{*}{$\begin{array}{c}\text { Gross Revenue } \\
\text { (OMR/Year/Household) }\end{array}$} & \multicolumn{2}{|c|}{$\begin{array}{l}\text { Land Extent Cultivated } \\
\text { (Hectares) }\end{array}$} & \multirow[t]{3}{*}{$\begin{array}{l}\text { Land Use Inten- } \\
\text { sity (\%) }\end{array}$} & \multicolumn{3}{|c|}{ Labor Use (Persons) } \\
\hline & & & & & & Omani & Expatriate \\
\hline & & Spring & Sumer & & Family & $\begin{array}{l}\text { Non } \\
\text { Agricultural }\end{array}$ & Hired \\
\hline Family Labor & 1061 & 0.66 & 0.66 & 7.5 & 0.55 & 0 & 0 \\
\hline $\begin{array}{c}\text { Family Labor } \\
+ \\
\text { Non-agricultural }\end{array}$ & 5304 & 0.58 & 0.49 & 61 & 0.33 & 1 & 0 \\
\hline $\begin{array}{c}\text { Family Labor } \\
+ \\
\begin{array}{c}+ \\
\text { Non-agricultural } \\
+ \\
\text { Hired Labor }\end{array}\end{array}$ & 4973 & 0.66 & 0.66 & 75 & 0 & 1 & 0.55 \\
\hline
\end{tabular}

employment to improve household income. The full extent of 0.9 ha is not cultivated and only $75 \%$ land use intensity is achieved. Of a total availability of 1.33 Persons/ Year of family labor, only 0.55 Persons/Year is used in farming. As evident in row (2) of table 2 a single family member employed in non-agricultural sector increases the income to 5304 OMR/Year/Household. However the land use intensity decreases by $11 \%$ (from $75 \%$ to $61 \%$ ) resulting to a decrease in farm production. The decrease in land use intensity is caused by scarcity of family labor. Hiring labor for farms below 2.1 ha is illegal. However, if hypothetically the farm is allowed to hire 1 Person/ Year permanent labor, that would increase land use intensity but the farm income would decrease to 4973 OMR/Year/Household (row 3 in table 2) and only 0.55 Persons/Year of hired labor would be used in the farm. Hence it is not rational to hire permanent labor to small farms for farming activities only. Hired permanent labor if allocated to farm and other household work may be rational and would also increase land use intensity thus farm production.

The farm optimization results for a 2.1 ha farm are given in table 3 (scenario 2). As evident from line (1) use of only family labor achieves only $75 \%$ land use efficiency. It is also that the gross revenue is 2502 OMR/ Year/Household which is below the national poverty line which is $3600 \mathrm{OMR} /$ Year/Household. Thus there is an incentive for Omani labor to move to non-agricultural employment and as evident in line 2 with non-agricultural employment of 1 Omani labor household income increases 2 fold to $5320 \mathrm{OMR} /$ Year/Household. However land use intensity decreases to $28 \%$ with resulting decrease in farm production, due to labor scarcity. The shadow price of labor (marginal value product of labor) is estimated as $102 \mathrm{OMR} /$ Month/Person and compared to the wage for hired expatriate labor $60 \mathrm{OMR} / \mathrm{Month} /$ Person, justifies hiring of labor. With employment of 1 expatriate labor per 2.1 ha (5 Feddans) as per government labor legislation, the gross revenue increases to 6414 OMR/Year/household and achieves a land use intensity of $75 \%$. However it is found that labor constraints prevail during planting and harvesting periods and allowing for temporary labor employment for those pe- riods, increases the gross revenue to 6632 OMR/Year/ Household and land use intensity to $94 \%$ resulting to increased farm production.

In conclusion, income from an average 0.9 ha farm that uses family labor is below the national poverty line of a household, providing strong incentives for farmers to fetch for non-agricultural employment with legislated higher income. Oman has thus been experiencing a movement of labor from agriculture to non-agricultural sector at the cost of reduced land use intensity and thus reduced local food production. On the other hand, relatively larger farms of 2.1 ha too do not generate enough income, to be above the poverty line. This is the incentive for family labor to move out of agricultural to the non-agricultural employment to increase household income. As a consequence farm land is abandoned resulting to low land use intensity and reduced local crop production (scenario 2). Thus the current policy of legislatively allowing employment of 1 expatriate labor per 2.1 ha is optimal in terms of increasing Omani household income and agricultural land use intensity. Land use intensity could be further improved by allowing temporary employment of labor during labor peak requirements of the farm.

The current government policy intervention in the labor market through legislatively determining wage rates in the non-agricultural sector and the low productivity of the farm sector provides and incentive to Omani farm labor to leave agriculture. As a result farm production is reduced. The current policy of allowing the employment of 1 expatriate labor per 2.1 ha (5 Feddans) farm is optimal with allowing for hiring temporary labor during peak labor demanding periods. The gross income and land use intensity of farms could too be improved with allowing for employment of temporary expatriate labor to substitute the Omani labor that moves to non-agricultural labor. A flexible labor market policy of allowing temporary labor hiring will improve Omani household income and local farm production. However the implications of non-Omani management of farms and the long-run feasibility of hiring expatriate labor for farming need to be examined to ensure sustainable farming and food security in Oman. In the long run agricultural pro- 
Table 3. Farm optimization results for 2.1 Hectare farm (Scenario 2)

\begin{tabular}{|c|c|c|c|c|c|c|c|}
\hline \multirow[t]{3}{*}{ Labor Allocation } & \multirow{3}{*}{$\begin{array}{c}\text { Gross Revenue } \\
\text { (OMR/Year/House- } \\
\text { hold) }\end{array}$} & \multicolumn{2}{|c|}{$\begin{array}{l}\text { Land Extent Cultivated } \\
\text { (Hectares) }\end{array}$} & \multirow[t]{3}{*}{$\begin{array}{l}\text { Land Use Intensity } \\
\text { (\%) }\end{array}$} & \multicolumn{3}{|c|}{ Labor Use (Persons) } \\
\hline & & & & & & Omani & Expatriate \\
\hline & & Spring & Sumer & & Family & $\begin{array}{l}\text { Non } \\
\text { Agricultural }\end{array}$ & Hired \\
\hline Family Labor & 2502 & 1.60 & 1.54 & 75 & 1.3 & 0 & 0 \\
\hline $\begin{array}{c}\text { Family Labor } \\
+ \\
\text { Non-agricultural }\end{array}$ & 5320 & 0.58 & 0.58 & 28 & 0.33 & 1 & 0 \\
\hline $\begin{array}{c}\text { Family Labor } \\
+ \\
\text { Non-agricultural } \\
+ \\
\text { Hired Labor }\end{array}$ & 6414 & 1.60 & 1.54 & 75 & 0.33 & 1 & 1 \\
\hline Temporary Labor & 6632 & 1.97 & 1.97 & 94 & 0.33 & 1 & 1 \\
\hline
\end{tabular}

ductivity need to drastically improve to retain Omanis in agriculture with simultaneous removal of labor market distortions.

\section{References}

Al Said F, Zekri S, Khan IA. 2007. Profitability analysis of selected farms in the Batinah region of Oman, Agricultural and Marine Sciences, 12:1-12.

Apergis S, El-Montasser G, Sekyere E, Ajmi AN, Gupta R. 2014. Dutch disease effect of oil rents on agriculture value added in Middle East and North African (MENA) countries, Energy Economics, 45, 485-490.

Becker G. 1965. A Theory of the Allocation of Time, Economic Journal, 75, 493-517.

Donnellan T, Hennessy T. 2012. The labor allocation decisions of farm households: Defining a theoretical model, Comparative analysis of factor markets for agriculture across member states, Working paper, www.factormarkets.eu, ISBN 978-94-6138-238-2.

Gould BW, Saupe WE. 1989. Off-Farm Labor Market Entry and Exit, American Journal of Agricultural Economics, Vol. 71, Issue 4, 960-969.

Huffman WE, Lange MD. 1989. Off-farm work decisions of husbands and wives: joint decision making, The Review of Economics and Statistics, Vol. 71, No. 3, 471-480.

Mathenge MK, Tschirley D. 2007. Off-farm Work and Farm Production Decisions: Evidence from Maize-Producing Households in Rural Kenya, Paper submitted for the CSAE Conference 2007 on 'Economic Development in Africa', St. Catherine's College, University of Oxford, UK: March 18-20, http:// www.csae.ox.ac.uk/conferences/2007-EDiA-LaWBiDC/papers/408-Mathenge.pdf (01/07/2015).

MAF. 2008. Report on results of a study on cost of production of crops and livestock in the Sultanate of Oman (2007-2008), Agricultural and Fisheries Development Fund, Ministry of Agricultural and Fisheries
(MAF), Sultanate of Oman.

MAF. 2013. Agricultural Census of Oman, Ministry of Agricultural and Fisheries (MAF), Sultanate of Oman.

Mbaga M, Kotagama H. 2010. Food demand survey: Indicative demographic trends, A Consultancy Report submitted to GRM International, 15 May 2010, https://www.researchgate.net/publication/264895677_Food_demand_survey_Indicative_ demographic_trends_A_Consultancy_Report_submitted_to_GRM_International_15_May_2010.

MNE. 2010. The important result of household expenditure and income survey results from $20 / 5 / 2007$ to 19 /5/ 2008, Ministry of National Economy (MNE) Sultanate of Oman, Directorate General of social statistics.

Nasir M, Hundie B. 2014. The effect of off farm employment on agricultural production and productivity: Evidence from Gurage Zone of Southern Ethiopia, Journal of Economics and Sustainable Development www.iiste.org ISSN 2222-1700 (Paper) ISSN 22222855 (Online) Vol.5, No.23:85-98.

Reed M. 2012. Specific food security concerns in Oman, Keynote presentation at the International Conference on Food security in Arab Countries, Sultan Qaboos University, Mind Over Matter, 2:42-44.

Royal Decree. 2013. http://www.muscatdaily.com/Archive/Oman/Royal-Decree-on-standardised-salaries-grades-schedule-issued-2syn\#ixzz4VR79X4Ts.

Singh I, Squire L, Strauss J. 1986. Agricultural household models; extensions, applications and policy, The World Bank, http://documents.worldbank.org/curated/en/621291468739297175/pdf/multi-page.pdf

Weersink A, Nicholson C, Weerahewa J. 1998. Multiple job holdings among dairy farm families in New York and Ontario, Agricultural Economics, Vol. 18, Issue $2,127-143$. 